\title{
Missing the target
}

\section{When measuring performance undermines police effectiveness}

\section{ANDREW FAULL}

afaull@issafrica.org

Crime statistics can only offer a limited measure of police performance, if they can be a measure of performance at all. Many types of crime fluctuate completely independently of policing. To place pressure on the police to reduce crime statistics leads to perverse incentives, typically to not record crime (see the article by Bruce in this edition of SACQ). In South Africa, crime statistics are still seen as a measure of police performance rather than a measure of the challenge facing the police, and indeed society as a whole. Other police performance assessment measures currently in place also contribute to poor and abusive policing practices. This article explores these issues by drawing on research conducted in recent years, and through reference to the South African Police Service (SAPS) performance chart.

Police in democratic societies operate in a space forged between their constitutional mandate and the legal framework that defines how they must operate. The vision and mission of the SAPS, as based on the constitution, requires police to:

- Prevent, combat and investigate crime

- Protect and secure the inhabitants of the Republic and their property

- Uphold and enforce the law

- Create a safe and secure environment for all people in South Africa

- Prevent anything that may threaten the safety or security of any community ${ }^{1}$

Such a mandate is impossible for a police service alone to achieve; yet statements by police leaders, research on SAPS culture, as well as this author's experience as a police reservist, suggest most SAPS members nonetheless embrace the mandate. ${ }^{2}$

Given the high ideals of the mandate it would seem obvious that police participation in illicit activities would be detrimental to their effectiveness. But can police dishonesty, corruption, or crime ever be considered an enhancer of police performance? This article suggests it depends on who is doing the measuring, and how. It argues that current approaches to performance measurement in the SAPS may encourage disreputable and illicit actions by some in order to meet performance targets, rather than encouraging effective policing. The article argues that falsely positive assessments of achievement that hide illicit activity are an almost inevitable consequence of the measures of achievement as they currently exist. Additionally, the article suggests that that some of these illicit actions erode an already tenuous social contract between citizens and the police and that the measures of performance ignore the importance of citizen perceptions of police performance.

\section{AN EVOLVING POLICE CULTURE}

Informal rule bending has for decades been noted as a trend in police cultures, developing as a means to realise a mandate within a restrictive environment. Usually such cultures develop beyond the public gaze and remain informal, but 
this is not always so. Take for example the muchtouted rhetoric that became prominent in the second half of 2009, perhaps oversimplified by the media as 'shoot to kill'. While a clear call to the police to act illegally, in that the law prohibits the intentional murder of any person, it signified that a causal link was drawn between police use of force and police effectiveness. The national commissioner, minister and deputy minister of police, among others, repeatedly spoke of the need for police not deliberate over, or fear using lethal force against armed suspects, inferring that this would instil fear in the would-be criminal, and reduce crime. Analysts expressed concern that such rhetoric effectively encouraged police to act recklessly, or even to break the law by acting outside of the parameters of Section 49 of the Criminal Procedures Act governing police use of force. ${ }^{3}$ Although only at a stretch, the rhetoric can be interpreted as equating illegal police action with enhancing police performance.

While a more trigger-happy police service (or force) may serve to temporarily satiate public anger over crime, will it lead to a greater longterm citizen satisfaction with police performance? Unfortunately citizen satisfaction is not currently high up on the SAPS performance measurement agenda, while 'tough on crime' rhetoric appears an easy way to deal with public pressure.

\section{POLICING STATISTICS RATHER THAN CRIME STATISTICS}

One of the simplest and most visible ways in which both the SAPS and South African citizens measure police performance is through fluctuations in crime statistics. Individuals, shifts and stations receive monthly targets, which they need to meet in order to be seen to be functioning effectively. Former national commissioner, Jackie Selebi, notoriously lambasted station commissioners who failed to produce reductions in crime statistics, leading them to unrealistically pressure the men and women working beneath them. ${ }^{4}$

One negative side effect of the extreme organisational pressure on police commanders generated by a quota-based reduction system, has been the manipulation of crime statistics by station level members, as reported in the media in late 2009 and early 2010 (discussed in greater detail in the article by Bruce in this edition of SACQ). ${ }^{5}$ Although the SAPS would have us believe this truth-bending only happens in isolated cases, interviews conducted by this researcher with at least four current and former members in different parts of the country, including two former station commissioners, suggest such statistics-fixing is more widespread. ${ }^{6}$ In Beyond 'Good Cop'/ Bad Cop', Rajohane Matshedisho observes what he interprets as police viewing crime statistics, or the meeting of performance quotas, as more important than 'actual' policing. This provides corroboration for the views expressed in the interviews mentioned above.

Matshedisho illustrates how statistics-fixing does not only occur at the sinister level of manipulating already open cases, nor does it always necessarily involve rule bending. He recounts time spent with two members who stop and check cars as part of their shift assignment. The two police had been given a target of the number of vehicles that they needed to stop and search before the end of the shift. Matshedisho's observation was of the cops engaging in this task not as a crime prevention measure, as intended, but only to gather the information needed to complete the forms that would reflect the work they had done (e.g. writing down the licence number). Their work was motivated by a need to deliver on paper rather than in practice.

Similarly, many will have experienced driving through a SAPS roadblock only to have their driver's licence examined and its details recorded. Neither the car's roadworthiness nor the driver's blood alcohol levels are checked, and there is no search for contraband or firearms.

In these examples a performance target has been met and will be reflected in police records, but the police have not in reality accomplished anything of significance.

In a comparable experience in 2010, I was on patrol with two vans. One of the vans and its occupants 
began the evening shift by issuing fines to five separate vehicles for various road offences. Later in the evening when the same van came across an illegal taxi, and separately, an unlicensed urban drag racer (pounced on by six speeding police cars), neither was fined because it was felt enough fines had been issued for one evening. In this case there had been no dishonesty or offence committed on the part of the police. Instead, police discretion determined whether action was taken against the offenders. In this case the police felt they had achieved what was necessary, albeit according to artificial measures rather than the requirements of the rule of law (that everyone should be treated equally before the law).

In these examples police (in)action is based on a perceived need to meet particular quantitative targets, rather than on an understanding of the role and function of police in society.

\section{ENFORCING NO LAW}

But there is another form of police logic that encourages illicit deeds, yet is justified by police as facilitating justice. Take for example the story of a police inspector who left the service in 2006 . He recounted how, when the opportunity emerged, he would facilitate the exchange of cash between the perpetrator and victim of an assault in instances where the two knew each other, in order to have charges withdrawn. In return he would pocket a 'commission' from the two. He believed this benefited both parties and produced a better result than would have been achieved by the criminal justice system:

I don't have any feelings about it being wrong. Sometimes when you do something that helps you, you become happy. I also helped those guys. I restored their relationship. The one did not go to jail and the other one was fine with it. ${ }^{8}$

This kind of action serves a dual purpose, as another inspector explains:

If I must take all the cases that people want to report when there's a possibility that they will withdraw it the next morning, there would be ten times more cases. So you settle things with them and you work things out, otherwise you will be told you haven't done your job. I've seen a case where it was nearly a murder and the victim said, 'Just pay the medical expenses and I will forget it'. They knew each other and were drinking together. ${ }^{9}$

Does this type of rule breaking aid police performance? The fact that these crimes are not registered contributes to a veneer of low crime while at the same time the police member convinces him- or herself that both offender and perpetrator are better off having avoided formal judicial procedures. On paper then, and in the minds of the police involved, police performance has improved.

\section{CHARTING POLICE PERFORMANCE}

Reductions in station level crime rates are the holy grail of a station commissioner's performance assessment as measured by the SAPS Performance Chart. Eighty per cent of a station commissioner's personal performance measurement is derived from the highly complex chart. $^{10}$

The chart provides measurements for police stations according to three categories: operational performance, data integrity and resource management. It refers to, but currently does not provide, due to difficulties in measuring this, a rating for community satisfaction. The three categories are not evenly weighted. Eighty-five per cent of the ultimate measurement of performance, which is presented as a series of scores, is made up from quantitative data relating to operational policing (e.g. reported crime, cases to court, detection rate, response times, etc.). But not all crimes are measured in the same way. Weighting is given to crimes based on their nature and priority, with violent crime (referred to by the SAPS as 'contact crime', e.g. robbery, murder, rape, assault, etc.) most heavily weighted. Crime statistics generated by policing activities (e.g. drunk driving, drug arrests, firearm recovery) carry no weighting. In other words, a high 
number of reported contact crimes will reduce a police station's performance score. Although crime statistics generated by policing activities are viewed in a positive manner and are guided by quotas, increases in these statistics do not improve a station's performance score unless a suspect is sent to court and sentenced, in which case they count favourably.

Considering the rituals in which station commissioners have been made to stand up in front of their peers and account for the low performance scores of their police stations, ${ }^{11}$ it is understandable that any pressure exerted on a station commissioner is transferred to his or her members. For example, at a station where I was working in 2006 an instruction was issued that police officers should discourage victims of assault from opening cases. The logic was that assault cases are so often thrown out of court or withdrawn by complainants, that they were better left off the station's records. Although it is easy to see how the station members could easily accept this logic as legitimate, the result is that police management have no idea how much assault is taking place in their precinct and therefore will not be able to identify it as an emerging problem. Furthermore, station management could erroneously claim that they had reduced assault, when in fact the opposite could be occurring. By not recording crime, the police undermine the ability of government to identify problems, develop solutions and assess impact.

\section{PUBLIC PERCEPTIONS AND POLICE ABUSE}

The assessment or measurement of police performance policies is not only an internal police matter. Ultimately police need to satisfy the public. The 2007 ISS Victims of Crime Survey asked respondents whether they felt the police were doing a 'good job' or a 'bad job'. Promisingly, more felt they were performing well (49 per cent) than badly (38 per cent). The most common affirmations for good police performance were the perceptions that police 'arrest criminals' (37 per cent), 'respond on time' (36 per cent) and 'are committed' (32 per cent).
Negative views of police performance were based on perceptions that they 'don't respond on time' (56 per cent), 'are lazy' (26 per cent), 'don't come to my area' (23 per cent) and 'are corrupt' (22 per cent).

Police response times - vital to citizen perceptions of police - are measured by the SAPS performance chart, as are arrests. However, in order for police to meet the public requirement of being seen to be 'arresting criminals' they need to formally process individuals through the justice system by means of arrest, investigation and prosecution. Perhaps through a combination of pressure to perform, lack of citizen support, and investigative incompetence, some police feel compelled to abuse or torture suspects in order to achieve these results. Although not yet empirically investigated on a large scale, reports of torture in the media and investigations conducted by the Independent Complaints Directorate (ICD) suggest abuse and torture may be routine. ${ }^{12}$ As a former member of Crime Intelligence in the Free State put it:

I don't care who says what, if you're not going to torture somebody, you're not going to get much information. That's just the way it is. Liberals hate to hear that. But they like the result. ${ }^{13}$

But it's not only retired cops who tell such tales, as this Johannesburg-based detective constable shows:

If you want to know more about a suspect you must interrogate him. Sometimes we use illegal means to get information from the suspect. Sometimes you must moer him. Sometimes you must break the law to get the information... Unfortunately there's no other way. Most of these people are hardened criminals. They are not afraid of police officers. They won't tell you anything unless you make them tell you. ${ }^{14}$

And this serving Western Cape Organised Crime detective:

I've been involved in the usual - a sack over the head and you throw water over him, or you tube 
him - but not anymore. Although it still

happens, I don't participate. I believe that it's sometimes still the right thing to do... It

happens a lot in Organised Crime. ${ }^{15}$

In Beyond 'Good Cop'/'Bad Cop' Matshedisho notes the manner in which police use of violence as a policing tool has become inculcated at one Gauteng station. Preparing to beat a suspected hijacker, a shift constable tells Matshedisho, 'Now we are going to do our duty', following which the suspect is beaten and made to inhale pepper spray from a plastic packet. Matshedisho sees police use of violence as a show of power, but also as a performance enhancer in as much as it is used to solicit confessions or information and effect arrests. ${ }^{16}$

In each of these examples the police involved have clearly legitimised their illegal actions as being necessary to accomplish their crime reduction mandate and improve their performance. That such attitudes are held by members playing such different policing roles, and in different provinces and cities, suggests they have become accepted, if not throughout the organisation, then in pockets across the country.

\section{CONSENSUAL POLICING (BY FORCE)}

In Thin Blue Jonny Steinberg paints a portrait of contemporary South Africa as a country in which citizens have yet to consent to being policed. ${ }^{17}$ It is one in which two patrolling police will corner a thief in an alley but leave enough space for him to escape, satiating bystanders' need to see the police in action but without exerting any authority which the public has not granted them. In Steinberg's reading, this dance on the part of police is a means to appear to fulfil their mandate within the constricts of a public's withheld consent. His depictions present police officials without legitimacy or power.

However, he contrasts this image with one of a team of police roaming the township streets in a pack and stamping their authority on those around them. This group does not see its work as extending beyond the end of the shift.

Information is gleaned regarding the whereabouts of an illegal firearm, but is not passed on at the end of the evening, the information presumably lost forever. Among the possible motivating factors behind this (in)action one should consider the fact that the seizing of an illegal firearm would be considered a 'police generated crime', one that is not given weighting in the SAPS Performance Chart unless it leads to a positive conviction. Although the other arrests made by the group that night would have been similarly 'police generated', the firearm required action beyond their delineated working hours; would not have scored the station or shift either positive or negative performance points; and was ignored. Like the police member I observed declining to fine a drag racer because it was felt enough fines had been issued for the evening, these police may have already met their quota for recovered firearms for the month, or, more likely, had not been issued with a quota, so had not felt compelled to follow the lead. If the latter is the case, it reveals another negative ramification of a quota-based performance measurement system.

Can a connection be made between a population's consenting to being policed and police use of force? Most definitely. In The Dirty Work of Democracy Antony Altbeker recounts meeting a detective in Hillbrow who says that '[When arresting someone in Hillbrow], if they think you are weak, that is when they will come after you. The only way is for them to fear us. It's as simple as that: if they don't fear us then they shoot. ${ }^{18}$ This detective claimed to have fired his weapon in about twenty incidents, including waiting for a car thief to step out of his own vehicle before shooting him. The detective's words and alleged actions hark to the current police leadership's 'shoot to kill' rhetoric, as well as the testimonies of the police members quoted above. Altbeker notes that this officer's view is not representative of the service, but also that for a cop to hold such a view he must live it; he must be hard. It would seem that South Africans increasingly expect their police to be just this: hard. 
Do police really need to be 'hard' and liberal with their use of force and violence in order to 'arrest criminals', 'respond on time' and 'be committed'? Although it is easy to see how a culture may develop that sees violence as a means to these ends, it is not necessary that it should.

Acclaimed police academic, David H. Bayley, suggests that for a police service to be truly effective it must demonstrate that it is responsive, available and fair to the population. ${ }^{19} \mathrm{He}$ bases this on the premise that police are the tool for legitimising the law and mobilising public support for a moral regime. Although Bayley agrees that this is accomplished through the provision of security, it is easy to see how this provision, if based on illegitimate means, serves to delegitimise the police. Bayley believes only about fifteen police organisations in the world realise this mandate of responsiveness, availability and fairness. The SAPS is not one of them. In this light, police leadership in South Africa could be said to be sending the wrong message, as a 'tougher', more violent police service is likely to further undermine the social contract that allows police to function effectively.

\section{CONCLUSION}

Police performance is assessed on the basis of operational performance indicators, such as the number of contact crimes recorded, response times, and number of cases to court. Although 'community satisfaction' forms part of the SAPS performance chart, it carries no weight and remains almost entirely unmeasured at most stations. 'Community perception' as a whole remains entirely unmeasured. This is problematic, particularly considering less than half of adults in South Africa consider the police to be doing a 'good job'. Not only do negative perceptions undermine the legitimacy of the police, but also potentially that of the government and rule of law.

The 'community satisfaction' portion of the SAPS performance chart needs to be developed and applied at all stations and given a reasonable weighting, in order for the chart to more holistically assess levels of police performance.
Possible forms this could take are regular exit polls at police stations or annual surveys conducted in station precincts. Whether these rather costly methods are used, or a simpler, more streamlined system is developed, this aspect of the chart should be prioritised for completion.

South African police are stuck between a need to perform, based on the performance chart, and to meet the principles of community centred policing. Perhaps most importantly, they need to perform in a manner that will win over the people of this country so that they will consent to being policed. While getting tough on criminals through the use of torture, and the adoption of 'shoot to kill' attitudes may appear to satiate public needs, the misdirection and abuse of force in the long run is likely to do far more harm than good to public perceptions of police, not to mention that such acts are often illegal. If positive perceptions decline, already scarce citizen-volunteered information may become harder to come by, leading to a further reliance on strong-arm short cuts to achieve results.

Ultimately, it is clear that within the framework in which police performance is currently conceptualised and monitored, some illegal and illegitimate acts occur because they are seen to increase police performance as measured by the SAPS: for example, by diverting would-be cases away from official records so as to reduce crime statistics, or forcefully extracting information from a suspect in the hope that it will aid investigations. As important as the SAPS performance chart is in its current form, a paradigm shift is needed so that members do not equate good policing with meeting performance quotas. Police action should always be motivated by a sound knowledge of police purpose, and should involve a consistent application of the law. Until we see police legitimacy as the ultimate measure of police performance, illegitimate activities that enhance current measures of police performance will continue, and the risk that the police alienate themselves from the population will grow. 
NOTES

1 South African Police Service, Visions and Mission, available online at http://www.saps.gov.za/org_profiles/ vision_mission.htm (accessed 28 January 2010).

2 Examples of research exploring police culture in South African include: M Marks, Transforming the Robocops: changing police in South Africa, Durban: University of KwaZulu-Natal Press, 2005; J Hornberger, 'Don't push this constitution down my throat!' Human rights in Everyday Practice. An Ethnography of Police Transformation in Johannesburg, South Africa, unpublished $\mathrm{PhD}$ thesis, University of Utrecht, 2007; A Altbeker, The Dirty Work of Democracy, Johannesburg: Jonathan Ball Publishers, 2005; J Steinberg, Thin Blue: the unwritten rules of policing South Africa,

Johannesburg: Jonathan Ball Publishers, 2008; A Faull, Policing Diversity: an analysis of a diversity intervention and its effects on a South African Police Service station, Amsterdam: Rozenberg Publishers, 2008; D Vigneswaran \& J Hornberger (eds.), Beyond 'Good Cop'/'Bad Cop': Understanding informality and police corruption in South Africa, Johannesburg: University of the Witwatersrand, 2009; and A. Faull, Behind the Badge: the untold stories of South Africa's Police Service members, Cape Town: Zebra Press, (forthcoming in May 2010).

3 Section 49 of the Criminal Procedure Act (51 of 1977).

4 This statement is based on a discourse in police circles which refers to 'Selebi-gate' or 'the Selebi trials' - the former commissioner's emphasis on crime statistics as the ultimate measure of police performance and his public embarrassment of station commissioners who failed to keep statistics down. During fieldwork in April 2009 the former commissioner of a Gauteng station explained to this author that he was forced to manipulate statistics in order to avoid public humiliation. See also: S Alcock, Fear made police cook stats, 11 July 2009, Mail \& Guardian Online, http://www.mg.co.za/article/ 2009-07-11-fear-madepolice-cook-stats (accessed 14 August 2009).

5 See for example: S Alcock, Crime stats scam exposed, 5 July 2009, Mail \& Guardian Online, http://www.mg.co.za/article/2009-07-05-crime-statsscam-exposed (accessed 14 August 2009); S Alcock, Fear made police cook stats, 11 July 2009; L de Vries, Petros faces press on stats allegations, 25 June 2009, Independent Online, http://www.iol.co.za/ index.php?set_id=1\&click_id=13\&art_id=vn200906251 04808219C442522\&page_number $=2$ (Accessed 9 February 2010); C Smith, Probe fingers top FS cops, News 24.com, 15 January 2010, http://www. news24.com/Content/SouthAfrica/News/1059/ca3cda6 b75d04e238a2163d4fbc4770f/15-01-2010-07 54/Probe_fingers_top_FS_cops (Accessed 9 February 2010).

6 Faull, Behind the Badge.

7 R Matshedisho, Concept Note Eight: 'We must fight them!' Police violence, torture and brutality in Vigneswaran \& Hornberger (eds.) Beyond 'Good Cop'/'Bad Cop': Understanding informality and police corruption in South Africa.

8 Faull, Behind the Badge.
9 Ibid.

10 My information on the SAPS performance chart was gathered during a three-hour interview with a SAPS member responsible for working with and training in the chart. Although authorized to speak with me, the member requested that $s$ he remain anonymous in any publication.

11 See endnote 5

12 See for example Independent Complaints Directorate Annual Report 2008/2009, available at http://www.icd.gov.za/documents/index.html; S Alcock, The torture force, 2 March 2009, Mail \& Guardian Online, http://www.mg.co.za/article/200903-02-the-torture-force (accessed 10 February 2010); Report on torture cases investigated by the ICD, 2001, http://www.icd.gov.za/reports/torture.htm (accessed 10 February 2010); P Joubert, Cops in torture death probe, 6 April 2009, Mail \& Guardian Online, http://www.mg.co.za/article/2009-04-06-cops-intorture-death-probe (accessed 10 February 2010); Faull, Behind the Badge.

13 Faull, Behind the Badge.

14 Ibid.

15 Ibid.

16 Matshedisho, Concept Note Eight: 'We must fight them!'

17 Steinberg, Thin Blue.

18 Altbeker, The Dirty Work of Democracy.

19 D Bayley, presentation titled "The Police in War: Fighting Insurgency, Terrorism, and Violent Crime" made at the Politics, Theory and Methods of Policing Research: Innovations and Trends conference, Cape Town, 30 January 2010. 